Медіафорум : аналітика, прогнози, інформаційний менеджмент : 3б. наук. праць. - Чернівці :

Чернівецький нац. ун-т, 2021. -

Том 9. - C. 263-274
Mediarorum: Analytics, Forecasts, Information Management: Collection of Research Articles. - Chernivtsi: Chernivtsi National University, 2021. Vol. 9. - pp. 263-274

https://doi.org/10.31861/mediaforum.2021.9.263-274

УДК: 327: 77(084.122)

(C) Mykola Yeromin ${ }^{1}$

\title{
UNEXPECTED CROSSROADS OF INTERNATIONAL POLITICAL COMMUNICATION: INFLUENCE AND INSIGHTS OF UNIVERSAL CODES OF MEDIA AS EXEMPLIFIED BY PODCASTS, COMICS AND NEW MEDIA
}

The article dwells upon the original research conducted by author $d u$ ring and after his PhD studies. Through the case studies of media (exemplifying podcasts, comic books and unclassifiable new media such as web-series) directly influencing and/or vice versa being influenced directly by current political events, shown is the interconnecting tissue of universal codes of media, affecting the international political communication through media influence in unpredictable ways. Underlined is the crucial need to strengthen the awareness of experts and general population alike of such processes in Ukraine due to hybrid war occurring with Russian Federation.

Keywords: international political communication, new media, universal codes of media, universal code of movies, political communication studies, empirical sources, political studies, hybrid war.

\section{Несподівані перехрестя міжнародної політичної комунікації: вплив та інсайти універсальних кодів медіа} на прикладах подкастів, коміксів та нового медіа

У статті викладено оригінальне дослідження проведене автором під час- та після захисту кандидатської дисертації. Через кейси, щз демонструють прямий вплив медіа (на прикладах подкастів, коміксів та складних для класифікації нових медіа на кщталт веб-серіалів) та навпаки на них з боку сучасних політичних подій показано взаємозв'язок крізь універсальні коди медіа, які впливають на міжнародну політичну комунікацію непередбачуваним чином. Підкреслено

1 Кандидат політичних наук, співробітник кафедри міжнародних відносин і зовнішньої політики Донецького національного університету ім. Василя Стуса (м.Вінниця), Україна, E-mail: nikolayeriomin@gmail.com 
необхідність посилення обізнаності експертів та широкого загалу щодо таких процесів в Украйні в умовах гібридної війни з Російською Федерацією.

Об'єкти впливу у міжнародній політичній комунікаиї̈ є проблемними як з точки зору типології, так і з точки зору дослідження. Ця проблемність певною мірою стосується міжнародної політичної комунікації за ї̈ визначенням, але у конкретному випадку иієї статті стосується зростання кількості кейсів в яких експерти не здатні вгадати ступінь впливу певних медіа (а особливо художніх творів) на подіі в міжнародному політичному середовищі, а за типологією Дрешера цей вплив було б логічно характеризувати як иум (у протилежність пропаганді та фактичним висловам), якби не той факт, щзо за бажанням можна було б виокремити новий комбінований тип, здебільшого інтуітивний шум, який тим не менш має по собі частки аналітичної роботи і викликає однозначний резонанс серед суспільства. Серед кейсів проаналізованих у статті наведено традиційні та нові 264 медіа трьох основних напрямків: подкасти, комікси та складні для однозначної класифікацї нові медіа на кшталт веб-серіалів. Усі вони пов'язані через сбормульований у авторській монограбї комплекс універсальних кодів медіа, між ними знайдено кореляцію, яка також пропориійно пов'язана з впливом на міжнародну політичну комунікацію.

У випадку веб-серіалів «Зов Манна» та «Кіт Лазаньї» показано як шум крізь реблексію щодо концепції авторства у сучасному суспільстві та надання певної частини авторства аудиторії крізь інтерактивні елементи наповнюється принагідним політичним символізмом характерним для сучасного політичного суспільства у США, а також постбіполярної кризи розуміння «лівих» поглядів та фобіі щзодо них з боку обіиійного істеблішменту. Проведено паралель з РФ, котра позиціонуючи себе як «правонаступника» СРСР тим не мени вимушена прокладати собі шлях практично у «правих» політичних поглядах США, через певне переосмислення понять. У випадках подкастів розглянуто на прикладі Truе Capitalist Radio інтенцію шуму як політичний меседж сам по собі у політичному медіа. У випадках коміксів показано вплив класичних для иієї форми творів на сучасну популярну культуру що призводить до творення нових сенсів у протестних рухах. Це зокрема показано на прикладі того як створені на основі коміксу «Хранителі» повнометражний більм 2009 року та телесеріал 2019 року інтегрували реальні історичні подіi, проводя- 
чи сміливі паралелі які сприяли поширенню населенням історичного контексту у міжнародні політичній комунікації. На основі наведених кейсів зроблено висновок про ігнорування таких процесів населенням та експертними колами, що з одного боку підтверджує низьку обізнаність у медіа у населення країн що розвиваються, а з іншого засвідчує необхідність у бормуванні медіаграмотності у різних верств населення. Наголошено також на необхідності підвищення медіаграмотності в умовах гібридної війни України з РФ, котра активно використовує усі наявні медіа для поширення свого політичного впливу.

Ключові слова: міжнародна політична комунікація, пеw media, універсальні коди медіа, універсальний код кінематографу, дослідження політичної комунікачї, емпіричні джерела, політичні дослідження.

Assorted and rich influence of media on international political communication could be traced back to introduction of such instruments of mass media as radio and television, but today's world solidified the connection, also making it way more uncertain since recent technological ad265 vancements of the digital age effectively combined all of the previously existing types of media and out of this strange brew emerged new types, influence of which while largely eluding documentation is already seen in the political curriculum. The purpose of this article is to highlight the intricate connective tissue between such new (and newly rediscovered) types of media and political communication, which also became international on previously unseen scales as of now, also thanks to the Internet.

Objects of influence in political international communications are problematic for typology and research due to being vastly varied, although researches in that field are scarce and undervalued. As such, political studies are oftentimes way too clueless when something from 'left field' has direct and overwhelming influence on international political communication, to a point that it's hard to be ignored. Such cluelessness could be extrapolated on international political communication in general. It could be characterized as something very much proven to exist but escaping direct definitions to a point of still being (largely) a quasi-concept, decades after first being formulated. (Speier, 1952; Drescher, 1987; Jenson, Harrison \& Prange-Gstöl, 2013; Yeromin, 2021B)

A quasi-concept, which fits well into methodology of logical-intuitive analyses (Yeromin, 2021A) should not be viewed as an un-concept: it is, indeed, a legit type of concept in research paradigm. It might seem like a 
mere placeholder, but factually it is not, for something escaping definition could still be tangible enough to hold itself just well on record. (Jenson, Harrison \& Prange-Gstöl, 2013). Out of chosen examples of media, comics are arguably the closest to traditional ones, although decades of distancing on both sides made it a 'prodigal son' in the system of traditional media.

Podcasts are definitely a type of new media (in opposition to traditional ones), but rooted very much in traditional one: it is obvious that spoken word audio is deeply rooted in the tradition started by radio. There are, of course, types of new media which are practically endemic to Internet. Although, to a point, connections to certain types of traditional media could be traced back with no sufficient problem (blogs could be viewed as a continuation of writing traditions of editorial, for example).

Primary wildcard and main aspect of new media is unprecedented interactivity, at times to a point that audience could be considered willing or clueless co-authors of the piece. In many cases audience is more than willing to do exactly that, at times 'biting' more than they can 'chew' and 266 proving that this experimentation is still very much a path of trail and

- error. An astonishing example of that is The Cry of Mann, experimental live web-series by art collective Wham City which attempted to blend sensibilities of modern live streams on the Internet with that of traditional forms of TV series (most noticeably daytime soap operas) and theatrical performance, evoking a number of existing traditional media types such as soap opera format, a residual from the eras of radio and television. The ability to phone call the characters as the episode still airs bends the reality of narrative fiction in a number of specific ways. (TV Tropes, 2017).

A similar device was used in another web-series, Lasagna Cat. A second season of the latter that started in 2017 made people answer two simple questions using the phone line, making no restrictions on whether answers should be true, direct and/or in-context. Resulting season finale using just a portion of the answers provided was an eight-hour juggernaut of the video which lures audience into interactivity of community before making a final artistic statement on the media being parodied in the most shocking and blunt way possible, despite also being surreal, discreet and philosophical. A discussion of the role of narrative fiction's author in the increasingly commercialized media effectively made a large portion of the piece less relevant, but also strengthened the point as in circumstances of interactivity making the audience co-authors their own value as audience and value of the authorship is becoming all the more problematic, intriguingly sug- 
gesting deterioration of some of the most important social institutes, as well as certain socialist tendencies of the internet. (TV Tropes, 2013; Yeriomin, 2018).

As a traumatic residual of bipolar world and Cold War, leftist, communists and socialists have long been the 'boogeyman' of the American society (while not necessarily having any major role in forming the actual political agenda of the US), but many of the recent generations are much more open to discuss such ideas, imploring that social value of some events is far more important than their economic aspects. An important, if utterly baffling for many, that shift in American society also seems beyond the gasp of Russia which intriguingly finds itself defending right ideals on the 'Western front', despite also proclaiming itself a successor of USSR. Neither Cry of Mann nor Lasagna Cat ever touch upon that specific area and yet there is an increasing connection of art being opposed to ideas of the 'old world', left and right likewise, aiming for a new balance and new ideas bordering on controllable anarchy, which is an oxymoron in itself.

Both Cry of Mann and Lasagna Cat are mainly art commenting on art; however political messages and unexpected turns in political new media essentially work in the same vein. The case of True Capitalist Radio is an interesting one in that aspect, regardless of whether it was partially staged (which is suspected). Although it positioned itself as a radio, it is now mostly remembered for new media aspects and presence: mainly the ability to leave 'audio graffiti' pretty much derailed most of the show's agenda and effectively send it into territory of abstract humor. Viewed from today's perspective, a platform of political message became so overwhelmed by noise that noise itself became a political message. (TV Tropes, 2012) That also correlates with Drescher's typology of international political communication, which solidifies noise as a type of international political communication, one of three with propaganda and a factual statement. (Drescher, 1987).

Interestingly enough, said phenomenon was predicted in the comics when the notion of new media was virtually nonexistent (or at best theoretical, rooted in genres such as cyberpunk). Works such as V for Vendetta and Watchmen emphasize distribution of ideas through self-made media which forces traditional one to comply: the use of mass distraction (yet again what could be classified as noise) in V for Vendetta leads to idea being eventually heard despite oppressiveness of the state-controlled media, while Watchmen has small-time conservative press receiving a journal 
by a notorious vigilante, which sheds the light on a conspiracy, otherwise expertly hidden from general public with key witnesses either suppressed or murdered, something that in 1986 was still a fresh reminder of the Watergate conspiracy. So much so that 2009's adaptation of Watchmen for the big screen draws a direct parallel with same very vigilante being responsible for actually suppressing Watergate in an alternative universe of the movie. (TV Tropes, 2010; TV Tropes, 2011; TV Tropes, 2012B).

Despite being (to a point) prophetic, both works are so deeply rooted in media of the time of their writing, that any sort of continuation needs to be alternative history. Watchmen TV series, for example, had to be set in the world without the Internet. Ironically, the spread of its ideas was very much through the Internet, which amplified the fandom of the series (and source material) exponentially.

An important part of Watchmen series were multiple flashbacks and references to Tulsa race massacre of 1921. Audiences worldwide were shocked to learn that this particular event was not only non-fictional but 268 very much a blindspot of historiography internationally, rarely addressed

- at all. Knowledge of the incident due to TV series and assorted web articles surrounding it readily contributed to Black Lives Matter movement in 2020. (Vineyard, 2020) A simple logical chain of events is that public awareness of the accident made people cite and draw comparisons to it more often, but there are multiple implications apart from that, including a factor of aforementioned Internet already containing enough information for series to simply being a catalyst of people accessing such knowledge.

Comic-book inspired movie Glass addressed the power of new media in 2019, with YouTube videos used to thwart a conspiracy being a pivotal plot point. While that aspect of the movie was heavily criticized and considered unrealistic due to the fact that superpowers could be easily faked with visual effects in YouTube videos, such criticisms could be easily viewed as lacking media awareness, an epitaph to residual naïveté of 2010's, a decade that was yet to see the real scales of several case studies and media ingressions.

It should be noted that YouTube videos in Glass also depict three murders and two real-life criminals which in real world (regardless of other elements in the video) will contribute to how it will be treated by civilian audience and authorities alike. It is especially jarring to look at the criticisms after 2020 as footage of George Floyd being murdered by Derek Chauvin (which was on YouTube) easily demonstrates exactly that and po- 
litical implications are massive. Context of media easily weighs more in the long-term discussion, then said video's content. When confronted people who still uphold said criticisms (names are redacted for moral reasons) are unable to see the parallels between two cases, saying that hardly director M. Night Shyamalan was making a point about racism. In that particular case lack of media awareness shows up to a point of ignoring the point in such awareness itself. It sparks a question whether people in developing countries, (unlike people in the United States) are even capable to see through media's power, take it seriously enough and accept responsibilities and consequences, until it's way too late.

Similar point could be noted in the case of 2019's Joker, which quickly became an audiovisual epitome of protest, injecting several new symbols in anti-government protests seen literally all over the world: Beirut, Catalonia, Chile, Hong Kong, Lebanon and Santiago, among others. (Clarke, 2019) Ironically, predictions and criticisms of Joker as seen through the prism of traditional media were rather off the mark suggesting that the movie might result in mass murder incidents, such as mass shootings. As of May 2021 no such incidents were directly connected to the movie, unlike assorted public disturbances of very different kind, bearing strong political messaging and questioning authority, social equality and other important matters political science considers crucial.

As such, one of the main trends of 2019 (if not overall decade of 2010's which is up to debate) could be formulated as skeptical attitude towards narrative fiction's ability to formulate relevant messages, despite most criticisms were proven to be vain the very next year. What we're left with is a near-crystallized circumstantial evidence of deterioration of a certain kind of political expertise and acumen traditional media such as newspapers possessed for a long time.

Effectively we have to deal with a fact that we live in the world in which narrative fiction might be more effective in logical-intuitive analyses than specialized outlets which leads us towards conundrum of what exactly changed in a decade that things went in a direction completely opposing that of predicted. In the humble theory author proposes a crucial phenomenon was ignored way too long by political science, which resulted in said phenomenon's increased political power being utterly surprising to unsuspecting experts. Said phenomenon was formulated as universal codes of media in the research insight Universal Codes of Media in International Political Communications: Emerging Research and Opportu- 
nities. (Yeromin, 2020 C) The use of "universal" in the author's term is merely a simplification of the same nature as "universal values", which are used widely in political science. A true universality is, of course, nearly impossible to achieve, but near-universality simplified under the term "universal" is certainly within the realm of possible. (Annan, 2003).

In Ukraine media studies could be seen as those especially in demand since media awareness is a crucial resistance factor in hybrid war with Russia over occupied territories of Donetsk and Luhansk regions, as well as Crimea. One of main Russian assets in that struggle was proven time and time again to be residual cultural influence on Post-Soviet countries heavily interconnected with Soviet symbology and mythology. The Internet plays a crucial role in upholding that influence through free and legal availability of audiovisual products such as movies, TV series and TV shows from both Soviet and Modern Era on government-sponsored channels on biggest streaming platforms such as YouTube. Latter, being a United States business venture seems to be concerned about the fact hence 270 the introduction of a special identifiers when it comes to channels spon- sored even partially by governments of certain countries. Even when such identifiers are absent, sanctioned and compromised media are still very much identifiable to those who armed themselves with critical thinking, a natural 'self-defense' technique in the era when any and all media we see could potentially become a deadly weapon in the wrong hands. And when it comes the latter aspect it should be noted that aforementioned co-author cluelessness applies as much to governments who sanction such media since due to lack of appropriate research they're not able to predict the results of the use of new media but can't resist the temptation of doing that regardless since it grants assets on a global arena too valuable not to use.

In a situation like that increasing media awareness of the population is way more crucial than attempts of blocking, censoring and obstructing certain pieces of media, practices which were proven vain in the digital age, moreover strengthening the bootlegger's effect of increasing the public view of product's value the more it gets censored. While teaching the population and public administration about media awareness is far from an easy task, it is something that researchers in humanities and political science are eventually inclined to do in order to increase our chances in surpassing over the Russia's overwhelming (if increasingly chaotic and unfocused) media influence. 


\section{Джерела та література:}

1. Annan, Kofi. 2003. Do We Still Have Universal Values? United Nations, December 12. http://www.un.org/press/en/2003/sgsm9076.doc. htm

2. Cote, Joe. 2020. "What is New Media?" Southern New Hampshire University. February, 24. https://www.snhu.edu/aboutus/newsroom $/ 2020 / 02 /$ what-is-new-media\#: : text $=$ New $\% 20$ media $\% 20$ is $\% 20$ any $\% 20$ media,podcasts $\% 20-\% 20$ that $\% 20$ are $\% 20$ delivered $\% 0$ digitally. \&text $=$ Some $\% 20$ types $\% 20$ of\%20new $\% 20$ media,a\%20podcast\%20or\%20smartphone\%20app.

3. Clarke, Laurie. 2019. "Why Joker masks are the perfect political protest symbol”. Wired. 2 November. https://www.wired.co.uk/article/ joker-masks-protests

4. Drescher D. 1987. A typology of international political communication: Factual statements, propaganda, and noise. Political Communication 4 (2), 83-91.

5. Jenson, J., Harrison, D. \& Prange-Gstöl, H. 2013. Social innovation research in the European Union. Approaches, findings and future directions. Policy Review. Luxembourg: Publications Office of European Union.

6. Speier, Hans. 1952. "International Political Communication: Elite vs. Mass”. World Politics Vol. 4 3:305-317.

7. TV Tropes. 2010. "Film/Watchmen". August 1. https://tvtropes. org/pmwiki/article_history.php?article=Film. Watchmen\&more $=\mathrm{t}$

8. TV Tropes. 2011. "Comic Book/Watchmen". October 14. https://tvtropes.org/pmwiki/article_history.php?article=ComicBook. Watchmen\&more $=\mathrm{t}$

9. TV Tropes. 2012A. "Radio/True Capitalist". April 15. https://tvtropes.org/pmwiki/article_history.php?article=Radio. TrueCapitalist $\&$ more $=\mathrm{t}$

10. TV Tropes. 2012B. "Comic Book/V for Vendetta". July 17. https://tvtropes.org/pmwiki/article_history.php?article=ComicBook. VForVendetta\&more $=\mathrm{t}$

11. TV Tropes. 2017. “The CryofMann”. December 12.https://tvtropes. org/pmwiki/article_history.php?article=Series. TheCryOfMann\&more $=\mathrm{t}$

12. Vineyard, Jennifer. 2019 (Updated July 3, 2020). “The Tulsa Race Massacre Happened 99 Years Ago. Here's What to Read About It”. The 
New York Times. October 21. https://www.nytimes.com/2019/10/21/arts/ television/watchmen-tulsa-race-riot.html

13. Yeriomin, Nikolay. 2018. "Garfield, Lasagna Cat and Garfielf: Immortality of The Orange Cat Explained". YouTube. June 20. https:// www.youtube.com /watch? $=$ yUOqGaORA_4

14. Yeromin, Mykola. 2016. "Універсальність кінематографу у міжнародній політичній комунікації”. Політичне життя 2: 63-68. http:// jpl.donnu.edu.ua /article/view/2432

15. Єрьомін, М.Б. 2018. “Вплив аудіовізуального медіа на аналіз міжнародної політичної комунікації”. Регіональні студії 14: 92-96. https://journals.index copernicus .com/api/file/viewByFileId/541205.pdf

16. Mykola Borysovych Yeromin. «Brave Old World: Facing the Challenges in Universal Codes of Media.» In Universal Codes of Media in International Political Communications: Emerging Research and Opportunities. Hershey, PA: IGI Global, 2021A. http://doi:10.4018/978-17998-3808-1.ch008

272 17. Mykola Borysovych Yeromin. «International Political

- Communication: New Challenges and Old Uncertainty.» In Universal Codes of Media in International Political Communications: Emerging Research and Opportunities. Hershey, PA: IGI Global, 2021B. http:// doi:10.4018/978-1-7998-3808-1.ch001

18. Yeromin, Mykola Borysovych. Universal Codes of Media in International Political Communications: Emerging Research and Opportunities. Hershey, PA: IGI Global, 2021C. http://doi:10.4018/978-17998-3808-1

\section{References:}

1. Annan, Kofi. 2003. Do We Still Have Universal Values? United Nations, December 12. http://www.un.org/press/en/2003/sgsm9076.doc. htm

2. Cote, Joe. 2020. "What is New Media?" Southern New Hampshire University. February, 24. https:/www.snhu.edu/about-us/ newsroom/2020/02/what-is-new-media\#: : :text=New\%20media $\% 20$ is $\% 20$ any $\% 20$ media,podcasts $\% 20-\% 20$ that $\% 20$ are $\% 20$ delivered $\% 20$ digitally. \&text $=$ Some $\% 20$ types $\% 20$ of $\% 20$ new $\% 20$ media, a $\% 20$ podcast $\% 20$ or\%20smartphone $\% 20$ app.

3. Clarke, Laurie. 2019. "Why Joker masks are the perfect political protest symbol". Wired. 2 November. https://www.wired.co.uk/article/ joker-masks-protests 
4. Drescher D. 1987. A typology of international political communication: Factual statements, propaganda, and noise. Political Communication 4 (2), 83-91.

5. Jenson, J., Harrison, D. \& Prange-Gstöl, H. 2013. Social innovation research in the European Union. Approaches, findings and future directions. Policy Review. Luxembourg: Publications Office of European Union.

6. Speier, Hans. 1952. "International Political Communication: Elite vs. Mass”. World Politics Vol. 4 3:305-317.

7. TV Tropes. 2010. "Film/Watchmen". August 1. https://tvtropes. org/pmwiki/article_history.php? article=Film. Watchmen\&more $=\mathrm{t}$

8. TV Tropes. 2011. “Comic Book/Watchmen”. October 14. https://tvtropes.org/pmwiki/article_history.php?article=ComicBook. Watchmen\&more $=\mathrm{t}$

9. TV Tropes. 2012A. "Radio/True Capitalist". April 15. https://tvtropes.org/pmwiki/article_history.php?article=Radio. TrueCapitalist $\&$ more $=\mathrm{t}$

10. TV Tropes. 2012B. "Comic Book/V for Vendetta". July 17. https://tvtropes.org/pmwiki/article_history.php?article=ComicBook. VForVendetta\&more $=\mathrm{t}$

11. TV Tropes. 2017. “The Cry of Mann”. December 12.https://tvtropes. org/pmwiki/article_history.php? article $=$ Series. TheCryOfMann\&more $=\mathrm{t}$

12. Vineyard, Jennifer. 2019 (Updated July 3, 2020). “The Tulsa Race Massacre Happened 99 Years Ago. Here's What to Read About It”. The New York Times. October 21. https://www.nytimes.com/2019/10/21/arts/ television/watchmen-tulsa-race-riot.html

13. Yeriomin, Nikolay. 2018. "Garfield, Lasagna Cat and Garfielf: Immortality of The Orange Cat Explained". YouTube. June 20. https:// www.youtube.com /watch?v=yUOqGaORA_4

14. Yeromin, M. 2016. “Universal'nist' kinematografu v mizhnarodniy poliychniy kommunikatsii”. Politychne zhyttya 2: 63-68. http://jpl.donnu. edu.ua/article/view/2432

15. Yeromin, M.B. 2018. "Influence of audiovisual media in the analyses of international political communication". Rehionalny studiyi 14: 92-96 https://journals.indexcopernicus.com/api/file/viewByFileId/541205.pdf

16. Mykola Borysovych Yeromin. «Brave Old World: Facing the Challenges in Universal Codes of Media.» In Universal Codes of Media in International Political Communications: Emerging Research and 
Opportunities. Hershey, PA: IGI Global, 2021A. http://doi:10.4018/978-17998-3808-1.ch008

17. Mykola Borysovych Yeromin. «International Political Communication: New Challenges and Old Uncertainty.» In Universal Codes of Media in International Political Communications: Emerging Research and Opportunities. Hershey, PA: IGI Global, 2021B. http:// doi:10.4018/978-1-7998-3808-1.ch001

18. Yeromin, Mykola Borysovych. Universal Codes of Media in International Political Communications: Emerging Research and Opportunities. Hershey, PA: IGI Global, 2021C. http://doi:10.4018/978-17998-3808-1 